\title{
Effect of Compensation Factors on Employee Satisfaction- A Study of Doctor's Dissatisfaction in Punjab
}

\author{
Ayesha Yaseen (Corresponding Author) \\ MBA student at COMSATS institute of information technology, Lahore \\ Pakistan \\ E-mail: ayesha_yaseen@yahoo.com
}

Accepted: Feb 16, 2013 Published: March 05, 2013

Doi:10.5296/ijhrs.v3i1.3351 URL: http://dx.doi.org/10.5296/ijhrs.v3i1.3351

\begin{abstract}
:
Introduction- Doctors job satisfaction can be increase by providing good compensation system like valid pay, recognition, promotional opportunity and meaningful work. These factors have positive relationship with job satisfaction of doctors.

Objectives/Purpose- The aim of this research is to find out various issues of compensation management for the doctors in civil hospitals and to explore that compensation has direct effect on doctor's satisfaction level.

Research design/research methodology- This is a tentative research where survey has been conducted in well known civil hospitals of Punjab's main cities like Lahore, Faisalabad, Rawalpindi, Multan and Bahawalpur. Primary data has been assembled through questionnaire. And secondary data collected through research papers.

Findings- Findings have shown that pay, recognition, promotion opportunities, and meaningful work are factors of compensation management which have direct effect on job satisfaction on doctors. But the main reason of doctor's dissatisfaction is, because they are not getting proper service structure and not finding their work meaningful. Government should increase satisfaction of doctors by providing this type of non financial compensation.
\end{abstract}

Recommendation/suggestion- The most important thing is that government should revise and make amendment in the service structure of doctors. Because the main reason of doctors dissatisfaction in Punjab is actually the service structure. Government should implement proper performance management system to tackle the issues related to feedback, performance and promotions of doctors.

Contribution- This study plays a vital role in persuading the policy makers to think over the factors which effect on doctor's satisfaction in civil hospitals. The findings of this research are valuable, which can be useful for the worldwide in order to tackle such issues again.

Key words: Doctors, Compensation, Salary, Promotion opportunity, Satisfaction 


\section{Introduction:}

Human resource management becomes a significant aspect for an organization's prosperity. Because it is the human who built up and develop the organization, to effectively and efficiently achieve its objectives. Today human acknowledged as the most valuable asset for an organization so they should be properly administered (Kabene et al, 2006). Doctors are termed as the human capital of hospitals. So without proper compensation management, they can't be properly managed and retained. And we all know that hiring cost is much higher than retaining cost. We all know about the famous phrase, "health is wealth". So without a proper health protecting structure (hospitals), we can't assure about a country's prosperity. And it is necessary that doctors in hospitals are well compensated to achieve their goals effectively and efficiently. Doctors are the corner stone of hospitals. Without them, hospitals are nothing.

Now a day there is an emerging issue/conflict in Pakistan, which is the doctors' strike against the government by not fulfilling their demands. Young doctors continued their protest, and shouting motto against government. Their protest is started approximately two years ago. Due to this doctor's dissatisfaction with work increasing, disputes grievances stuck, they are not treating patient as they should treat and their turnover rate also increases. On 16 April 2012 doctor's demands exceeded, they ask for the service structure to the government. The demand for service structure exceeded and doctors of others were also convinced from this demand. According to daily-times newspaper 2 July 2012, doctors Masood sheikh indicated that there is a service structure but it is not properly implemented and need improvements. If errors removed in the service structure 13000 cadre doctors will be promoted which are waiting from last 16 to 20 years. According to Pakistan news-newspaper 1 July 2012 Mufti Khairullah pointed out that this type of act like strike which is against humanity and peace is totally against ISLAM.

In Quran Allah says (Surah Almaida Para \# 6)

"if you save one life you save the humanity".

This is the emerging issue and government can't neglect them because government is concerned and responsible for the people health and safety and there is no substitute of doctors. Doctors are dissatisfied with their work and want to government to fulfill their demands (FRANKLIN, 2006). Job dissatisfaction causes turnover and absenteeism. Job satisfaction is therefore very important to retain the employees with their job (Robbins, 2003). This research has explored various compensation factors that influence doctors for their work efficiency and effectiveness in flourishing their performance in order to meet institutional goals. Kreitner and Kinicki (2001) described that according to Herzberg theory, there are two factors of motivation Hygiene factors and motivator factors in which include factors like salary, recognition and need for achievement etc. According to Werner (2001), job satisfaction has several facets in which include work its self mean how much work is meaningful for people, salary which is paid to people, promotion opportunity for people, and recognition.

\section{Objective of Research:}

Following are the objectives of current study: 
- To ascertain different issues of compensation management of doctors in hospitals.

- To recommend and suggestions for future.

- To explore that compensation has directly effect on employee's job satisfaction.

- To elaborate that through compensation (direct and indirect) employees are more satisfied with their job.

\section{Literature Review:}

\section{Job Satisfaction}

Locke (1976) defined job satisfaction as "job satisfaction is actually an enjoyable and exciting emotional condition which someone get in their work". Job satisfaction is important for reducing turnover rate and increase motivation. Prior studies indentified that there are different instrument for managing job satisfaction like pay, recognition and working environment (Mathauer et al., 2006). People will be more committed and more productive during their job if they are more satisfied (Al-Hussami, 2008). Satisfaction and dissatisfaction not only depend of the job but also depend upon employee's expectation about job (Hussami, 2008).

Job satisfaction is considered to be the most important element in the organization. In order to succeed organization must keep their employees satisfied (Wubuli, 2009). RAMASODI (2010) indicated that Job satisfaction is a significant factor in healthcare sector for better performance. If doctors are satisfied then they will be more motivated toward patient care and health care system outcomes will be satisfactory. Job satisfaction is actually a mixture of job role, job responsibilities, incentive and rewards. Job satisfaction is a combination of extrinsic and intrinsic job satisfaction. Extrinsic job satisfaction includes all the external factors like communication style, supervisor co-operation, pay and working conditions while intrinsic job satisfaction includes type of work the worker's do and the duty considered by the employee. When employee is satisfied he will perform well in workplace. To satisfy employees, organization provides different facilities to employees like to provide good working condition, fairness in job, give promotion and rewards to employees because these are the elements which contribute to employee satisfaction (Parvin \& Kabir, 2011). Maslow's theory (1970) shows that need of people starts from basic to high level. These needs are present in every human being. If there is failure to satisfy basic need then next need in hierarchy cannot be achieved. People who have need of security; they will not go to higher needs if they are not satisfied with it.

\section{Pay and Job Satisfaction}

Heery and Noon (2001) defined pay as payment, in which include many components like basic salary, benefits, bonuses, pay for doing extra work and incentives" According to Erasmus, van Wyk and Schenk (2001) define pay, "is what an employee gets against his work after fulfilling his duty, include all type of financial and non financial rewards". Martocchio (1998) described that compensation include both intrinsic rewards and extrinsic rewards. Extrinsic rewards include monetary and non monetary rewards. Non monetary rewards include things apart from basic pay like benefits. Money is the indicator of motivation. 
Employee's performance will increase if they are highly paid. Money is considered as the reward which is given to employees against work, to support their family, and payment for the work which is done. Barton (2002) suggested that organization should take into account financial rewards like salary because it has strong influence on employee motivation and retention. Dessler (2008) indicated that employee pay includes all compensation factors which are given to him against his work.

Cowin's (2002) indicated pay is an important component for the retention of nurses because if they feel inequality regarding pay between their profession and others' profession, they got dissatisfied and disappoint with their profession.

Less pay as compared to work done is one of that extrinsic factor which is responsible for job dissatisfaction (Robbins, 2003). Yang, Miao, Zhu, Sun, Liu and Wu (2008) suggested that, in Chinese forces it is considered that pay and satisfaction influence each other. Pay has direct influence on satisfaction level of employee. NL (2012) described that pay is one of those satisfying variable which hindered reduces the dissatisfaction level of employees. If an employee is compensated according to his need, he will easily manage overload work if any emergency occurs. E.g. if earthquake comes or flood comes and nurses have to work overtime, they will happily do it. So remuneration is most satisfying factor.

Robbins (2001) described that Herzberg's motivation-hygiene theory tells that salary is one of those hygiene factors which eliminate job dissatisfaction. Salary is a factor which leads employees from dissatisfaction to no dissatisfaction. Expectancy theory described that people do effort because they want some rewards in term of money, promotion etc. People expect that if they work well in the workplace then their performance will increase and automatically their pay will increase and they will be promoted. This will cause increase in their job satisfaction level.

\section{Hypothesis}

H1: Pay has direct relationship with job satisfaction.

Ho: Pay has not direct relationship with job satisfaction.

\section{Recognition and Job Satisfaction}

Recognition is defined as "in organization employees are rewarded by different status, this process is called as recognition" (Danish et al., 2010). Intrinsic rewards like recognition, growth, feedback, opportunities lead employees more towards high job performance and motivation than extrinsic rewards like salary (Nel et al., 2001). Robbins (2001) described that through the recognition employee get appreciation and status like as a part of organization. Barton (2002) described that recognition is considered the most important factor among non-financial rewards in order to increase job satisfaction level of employees.

Romano (2003) pointed out that recognition is the component that is used to strengthen the relationship between organization and people. Through the recognition employee feel rewarded and motivated. By giving recognition to the employee's competitive advantage can be achieved. Lawler (2003) suggested that the well being of any organization depend upon how its human resource is treated. Organization achieves its well-being through giving rewards and recognition to its employees. Andrew (2004) described that employee becomes 
more loyal to their organization if organization recognizes their work.

Organizations are missing the very valuable component in the organization that is recognition. However the cost of practical implementation of this component is very low. Through recognition, employees are being realized that they are valuable for organization and employees feel appreciated through recognition (Sarvadi, 2005). Recognition is actually to show employees that their participation is valuable for the organization which ultimately increases motivation and performance of employees. The best use of recognition is in the performance management system. Rewards and recognition are used to increase motivation and job performance of employees (ROBERTS, 2005). Robbins (2003) described that recognition and promotional opportunities are considered to be the important factor for intrinsic job satisfaction. This is the factor which is used as a reward for the employee.

Human resource tool which is useful for the job satisfaction is salary and recognition (Mathauner et al., 2006). NL (2012) pointed out that our younger generation is motivated more through recognition than money. Young people are more active and vibrant. Recognition is the step through which they can be satisfied in their work. They required that someone like their work, make them to participate in decision making, and value them. It is seen that employees get more motivated through recognition than money. People of fresh blood are more energetic and dynamic so they want recognition regarding their work than others. Recognition can be provided through involving employees in decision making, by increasing their responsibility, by showing empathy towards them and provide them with succession planning and different opportunities to get high designation.

Robbins (2001) described that Maslow's theory tells about the self- esteem need of employee. This theory shows that recognition, status, development and growth are the factors which leads to motivation and ultimately leads toward job satisfaction. Herzberg theory indicated that recognition is one of those motivating factors which leads employee from no dissatisfaction to satisfaction.

\section{Hypothesis}

$\mathrm{H} 2$ : Recognition has direct relationship with job satisfaction

Ho: Recognition has not direct relationship with job satisfaction.

\section{Promotion Opportunities and Job Satisfaction}

Heery and Noon (2001) define promotion "getting high status in workplace by doing effective work, generally increase the status, position and remuneration of employee in the organization". Grobler et al. (2002) define promotion as "going towards upward position in the organization". Graham (1986) defines promotion as "shifting from lower designation to high designation within an organization and usually increases in pay package". If organizations are not giving promotion to their employees then employees will be dissatisfied and their turnover rate will be high (Shields and ward, 2001). When employees get promotion they will be more committed to their organization (De Souza, 2002). Pay and promotions are considered most important element for the employee satisfaction (Parvin \& Kabir, 2011).

Promotion has significant effect on employee satisfaction (Wubuli, 2009). There is positive relationship seen between job satisfaction and opportunity to develop (RAMASODI, 2010). 
If organization provides employees the factors of promotion like facilities, ability and skills, then employees will be automatically motivated and satisfied. Promotion and satisfaction has direct relationship (Naveed et al., 2011). Robbins (2001) indicated that Maslow's hierarchy of need theory also described that when esteem needs (autonomy, power, recognition and status) of people are fulfilled, they will be more satisfied with their job .Herzberg theory of motivation tells what employees demand from their job. Three need theories tell that there is a need of achievement and need for power in people. People will be more satisfied and motivated when their needs are fulfilled. Herzberg theory indicated that there are some components of motivation like growth, responsibilities, recognition, achievement and advancement which also leads to job satisfaction.

\section{Hypothesis}

H3: Promotion has direct relationship with job satisfaction.

Ho: Promotion has not direct relationship with job satisfaction.

\section{Meaningful Work and Job Satisfaction}

Meaningful Work Is Considered More Valued Factors Than The Rewards To Employees. Now A Day Employees Want Qualitative Work And Outcomes. Employees Want Their Work To Be Meaningful Or Them. Meaningful Work Is An Emerging Factor For Valued Outcomes Of Organization (Caudron, 1997; Towers Perrin, 2003). Towers Perrin (2003) Indicated That Meaningful Work Provides Value For The Organization As Well As Value For The Employee. Meaningful Work Is An Important Issue And Valued For Both Employee And Employer.

There are some other factors rather than money which any employee want to share with their community and home members. Such factors include sense of achievement and feelings of accomplishment of some task. This meaningful work is considered as a dividend to employee (Pocock, 2006). Outcomes, task characteristics and meaningful work are important for such people who have need for achievement (Hackman \& Oldham, 1976).

Job satisfaction cannot be separate from demand of meaningful work. It is the duty of managers to make work meaningful for their employees so that they can be satisfied with their job and due to these employees will show positive response in the organization (Ramayah et al., 2001). Meaningful work is actually the purpose of working through which they have to pass. Success, achievement and status are included in the meaningful work experiences (Pratt \& Ashforth, 2003).

\section{Hypothesis}

H4: Meaningful work has direct relationship with job satisfaction.

Ho: Meaningful work has not direct relationship with job satisfaction. 
Conceptual Framework:

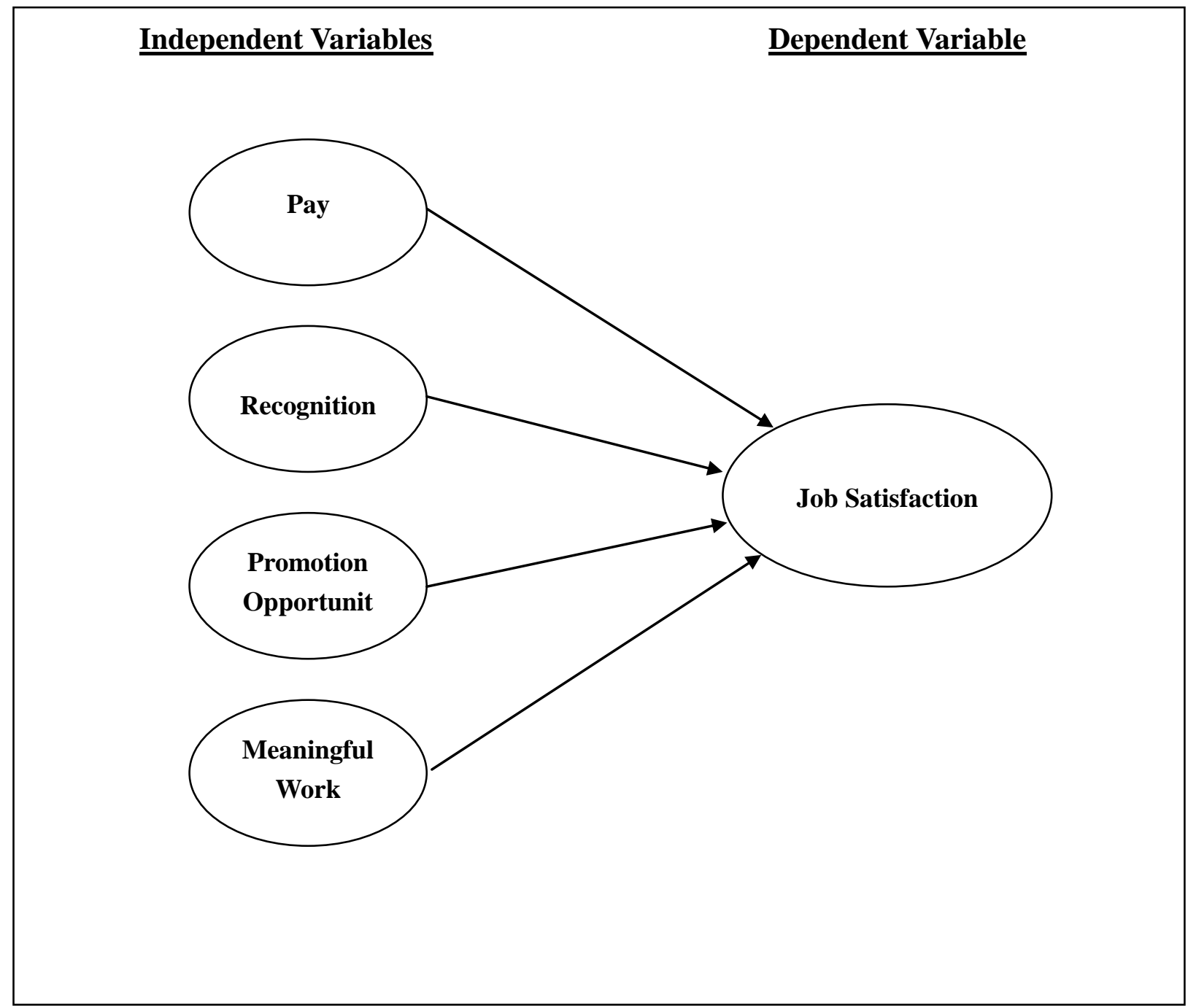

\section{Research Methodology:}

This tentative research supported through survey analysis which pointed out compensation factors which effects on doctor's job satisfaction. Government hospitals are taken for the research. In depth analysis is done through using questionnaires. A research is conducted to know the factors effecting on job satisfaction among hospitals of Punjab.

Primary and secondary data is used in this research. Primary source of data collection is used through questionnaires and secondary data is used through different articles, and research papers. Simple random sampling technique is used in this research. This study was conducted in government hospitals of Punjab, five major cities were selected for the research like Lahore, Faisalabad, Rawalpindi, Bahawalpur, and Multan because these were the major cities in which strike was conducted. A study population includes government hospitals in major 
cities of Punjab. Total number of M.B.B.S doctors which are registered in Punjab till 27 September 2012 are 52486 and total number of B.D.S doctors are 4602. Sample size is used by following formula in the book of "Business Research methodology" by Uma Sakaran.

A descriptive questionnaire was used which consists of 40 questions, categorized in 5 different sections of variables. 166 questionnaires were analyzed by using SPSS analytical tool. Co-relation and regression analysis is applied, which shows relationship between variables. Questionnaire consists of 5 different dimensions. Job satisfaction is taken as dependent variable and pay, recognition, promotion opportunity and meaningful work is taken as independent variable.

Questions are taken from already research paper. Data gather through questionnaire which is set out by De Beer (1987) and RAMASODI (2010).

\section{Data Analysis:}

Co-relation

\begin{tabular}{|l|l|l|}
\hline $\begin{array}{l}\text { Variables } \\
\text { (Independent Variables ) }\end{array}$ & $\begin{array}{l}\text { Pearson Co-relation } \\
\text { (Job Satisfaction) }\end{array}$ & $\begin{array}{l}\text { Significance } \\
\text { (2 tallied) }\end{array}$ \\
\hline Pay & $.529^{* * *}$ & .000 \\
\hline Recognition & $.684^{* *}$ & .000 \\
\hline Promotion opportunity & $.685^{* *}$ & .000 \\
\hline Meaningful Work & $.862^{* *}$ & .000 \\
\hline
\end{tabular}

**. Correlation is significant at the 0.01 level (2-tailed).

Pearson co-relation computed to determine

- Relationship between different independent variables and

- Relationship between dependent variable (job satisfaction) and independent variables (pay, recognition, promotion opportunity and meaningful work).

The results of Pearson Co-relation show that job satisfaction and all the other independent variables are positively related to each other and are more significant at 0.01 .

The Pearson value of 0.529 shows the strong positive co-relation between pays and job satisfaction. At the same time the significance level indicate the quite significant relationship at $1 \%$ significant level $(\mathrm{p}<0.01)$ which partially supports our first hypothesis.

The Pearson value of 0.684 shows the strong positive co-relation between recognition and job satisfaction. At the same time the significance level indicate the quite significant relationship at $1 \%$ significant level $(\mathrm{p}<0.01)$ which partially supports our first hypothesis.

The Pearson value of 0.685 shows the strong positive co-relation between promotion opportunity and job satisfaction. At the same time the significance level indicate the quite significant relationship at $1 \%$ significant level $(\mathrm{p}<0.01)$ which strongly supports our first hypothesis. 
The Pearson value of 0.682 shows the strong positive co-relation between meaningful work and job satisfaction. At the same time the significance level indicate the quite significant relationship at $1 \%$ significant level $(\mathrm{p}<0.01)$ which strongly supports our first hypothesis.

\section{Reliability Test:}

As far as reliability of the scales are concerned, the Cronbach's Alpha scores of Pay, Recognition, promotion opportunity, meaningful work and job satisfaction were $0.70,0.72$, 0.60, 0.92 and .804 respectively. Thus, all measurement scales are found to be reliable.

\section{Regression Analysis:}

Model Summary

\begin{tabular}{|l|l|l|l|l|l|}
\hline Model & $\mathbf{R}$ & R square & $\begin{array}{l}\text { Adjusted } \\
\text { square }\end{array}$ & $\begin{array}{l}\text { Std. Error of the } \\
\text { Estimate }\end{array}$ & Durbin-Waston \\
\hline 1 & .873 & .763 & .757 & .36248 & 1.776 \\
\hline
\end{tabular}

ANOVA

\begin{tabular}{|l|l|l|}
\hline Model & F & Significance \\
\hline Regression & 129.420 & .000 \\
\hline
\end{tabular}

\begin{tabular}{|l|l|l|l|l|l|}
\hline \multirow{2}{*}{ Model } & $\begin{array}{l}\text { Unstandardized } \\
\text { Coefficients }\end{array}$ & $\begin{array}{l}\text { Standardized } \\
\text { Coefficients }\end{array}$ & \multicolumn{2}{|l|}{ Significance } & \multicolumn{2}{|l|}{ Collinearity Statistics } \\
\cline { 2 - 6 } & $\mathrm{B}$ & $\mathrm{B}$ & & Tolerance & VIF \\
\hline Constant & .390 & & .001 & & \\
Pay mean & .050 & .056 & .312 & .478 & 2.091 \\
Rec mean & .015 & .017 & .801 & .344 & 2.911 \\
PO mean & .120 & .140 & .023 & .397 & 2.522 \\
MW mean & .648 & .726 & .000 & .383 & 2.610 \\
\hline
\end{tabular}

75\% variations in the dependent variable are explained by the independent variable in the model. $36 \%$ error in the predicated mean value of dependent variable is explained by the model. The value of Durbin-Waston test of 1.776 shows no auto co-relation exists in the model. The $\mathrm{F}$ ratio of 129.420 value $(\mathrm{p}<0.01)$ indicates the regression of dependent and independent variable, spoken through adjusted squared multiple ( $r$-squared adjusted $=75 \%$ ) is statistically significant. In the table of co-efficient, value of Beta is positive, which shows positive relation. It represents that if degree of any independent variable increase by 1 then dependent variable (job satisfaction) will go up by 1 degree. In Co linearity statistics the value of VIF which is $<10$, and tolerance level $>1$ indicates its significance. In regression analysis significance level of pay and recognition greater than 0.05 which is not significant but significance level of promotion opportunity and meaningful work less than 0.05 , shows highly significance with job satisfaction. But it is showing collective model significance. Significance level of 0.000 shows that the model is significantly fits the data at $1 \%$ significance level. 
Regression Equation:

$\mathrm{J} . \mathrm{S}=\beta_{0}+\beta_{1}$ (pay) $+\beta_{2} \quad($ Rec. $)+\beta_{3} \quad(\mathrm{PO})+\beta_{4} \quad(\mathrm{MW})+€$

$\mathrm{J} . \mathrm{S}=.390+.050$ (pay) +.075 (Rec. $)+.120(\mathrm{P} . \mathrm{O})+.684(\mathrm{MW})+€$

ANOVA Analysis:

Gender and Job Satisfaction

\begin{tabular}{|l|l|l|l|l|}
\hline Gender & Means & S.D & N & P \\
\hline Male & 2.9909 & .71641 & 96 & .131 \\
\hline Female & 2.8161 & .75353 & 70 & \\
\hline
\end{tabular}

One way ANOVA of gender and job satisfaction, there is .131 value of insignificant among them. The value of significant .131 is greater than the value of 0.05 . It represents there is no relation between gender and job satisfaction. A very little difference is in mean value, among male and female which is 2.99 and 2.81 respectively. That's why there is less variation finds across gender with job satisfaction.

Age and Job Satisfaction

\begin{tabular}{|l|l|l|l|l|}
\hline Age & Mean & S.D & N & P \\
\hline $25-30$ & 2.9912 & .55695 & 57 & .000 \\
\hline $31-40$ & 3.0995 & .66339 & 54 & \\
\hline $41-50$ & 2.5547 & .87173 & 48 & \\
\hline 50 above & 3.3929 & .67865 & 7 & \\
\hline
\end{tabular}

One way ANOVA of age and job satisfaction, there is (.000) value of significance among them. It represents that there is relation between age and job satisfaction. More than 50 age group people are less satisfied with their job because their mean value is 3.39 with (.678) standard deviation. People among 41-50 age group mean value with .871 standard deviation are more satisfied than people with 25-30 year age group and 31-40 year age group with mean value of .556 and .663 respectively. This shows that in different categories of age group, variation found with job satisfaction.

Experience

\begin{tabular}{|l|l|l|l|l|}
\hline Exp & Mean & S.D & N & P \\
\hline Less than 1 & 3.0870 & .49203 & 23 & .000 \\
\hline 1-2 year & 3.0036 & .59985 & 35 & \\
\hline 3-5 year & 3.1568 & .67795 & 55 & \\
\hline 6-10 year & 2.5377 & .82136 & 53 & \\
\hline
\end{tabular}

One way ANOVA of experience and job satisfaction, there is (.000) value of significance among them. There is a relation between experience and job satisfaction. People with 6-10 year experience reflect the high level of job satisfaction with a mean of (2.53) and standard deviation of (.821) than the people with less than 1 year experience and 1-2 year experience with the mean value of 3.08 and 3.00 respectively. This shows that in different categories of experience group, variation found with job satisfaction. 
Income

\begin{tabular}{|l|l|l|l|l|}
\hline $\begin{array}{l}\text { Income } \\
(\mathbf{0 0 0})\end{array}$ & Mean & S.D & $\mathbf{N}$ & $\mathbf{P}$ \\
\hline $10-20$ & 2.9643 & .52903 & 14 & .000 \\
\hline $21-40$ & 3.0523 & .57686 & 43 & \\
\hline $41-60$ & 3.1600 & .58958 & 50 & \\
\hline 60 above & 2.6017 & .87975 & 59 & \\
\hline
\end{tabular}

One way ANOVA of income and job satisfaction, there is (.000) value of significance among them. There is a relation between income and job satisfaction. Employees with above 60000 incomes reflect the high level of job satisfaction with a mean of (2.60) and standard deviation of (.879) than the people with 10,000-20,000 income and 21000-40000 income with mean value of 2.96 and 3.05 respectively. This shows that in different categories of income, variation found with job satisfaction.

\section{Findings and Discussion:}

In this portion results of analysis are discussed. To check the hypothesis Pearson co-relation, regression and Analysis of variance (ANOVA) are used. Results are made on the basis of acceptation and rejection of hypothesis.

$>$ Total 166 participants were involved in this study. Majority of participant were male than female with $66.3 \%$ and $33.7 \%$ respectively.

$>$ The maximum age of respondent was 31-40 year, which is $44.0 \%$. While minimum age of respondent was above 50 year which is $7.0 \%$.

$>$ Maximum respondent in experience was 3-5 year, which was 33.1\%. While minimum age of respondent was less than 1 year.

$>$ Maximum income of respondent was above 60,000rs, which were 35.5\%. While minimum income of respondent was 10,000-20,000, which were $8.4 \%$.

Overall mean of pay, recognition, promotion opportunities, meaningful work and meaningful work are $2.68,2.87,2.78,2.94$ and 2.91 respectively. Its sows that they are collectively disagree with the pay, recognition, promotion opportunity, meaningful work and job satisfaction, because their mean value is less than 3 (neutral).

Co-relation tables indicate that there is significant relationship between all the independent all dependent variables, therefore null hypothesis is rejected. These variables include pay, recognition, promotion opportunity and job satisfaction. Significance among the variables shows that there is positive relationship between dependent and independent variables. These results are supported by ROBERTS (2005), who conducted research on "The relationship between rewards and recognition with job satisfaction". This survey finds that most important things which excites employees is the pay, secondly recognition, thirdly promotion opportunity and meaningful work. These are considered most critical factors which effect on job satisfaction. These results are also supported by Mason (2001), his study reveals that many factors contribute to job satisfaction but pay, recognition, promotion opportunities and 
meaningful work are significantly relates to job satisfaction and considered as critical factors to job satisfaction.

The study reveals that there is no variance find between female job satisfaction and male job satisfaction both are equally satisfied with a mean value of 2.81 and 2.99 respectively. This is because government does not create biasness among male and female in relation to their salary, they are equally paid. This is insignificant with $1.31(\mathrm{P}>0.01)$. There is a difference between age group people with satisfaction. People with 41-50 year age group are more satisfied with mean value is 2.55 with (.678) standard deviation. People with age group of 25-30 and 31-40 are less satisfied with mean value of 2.99 and 3.09. Variance also finds in experience. People with more experience are found more satisfied with their job than the people with less experience. Our study shows that people with 6-10 year experience are found more satisfied than the less experience people. People who have job experience of 6-10 years, their mean value is 2.53 with .821 standard deviation are more satisfied. People with 1-2 and less than 1 year experience are found less satisfied.

There is variance finds among different income of people with satisfaction. People whose income is more than 60,000 are more satisfied their mean value is 2.60 with (.879) standard deviation. This study indicates that people with high age group, more experience and high income are more satisfied than people with low age group, less experience and low income. It is because doctors who have high income can meet their needs easily. It supports our literature which indicates that people who get more pay are more satisfied with their job. In the same way doctors who are more experience and are in high age group are more satisfied, because they may have their own clinic (other source of income). ANOVA analysis collectively shows that in gender there is no difference in satisfaction level but in age, experience and income there is variance found.

The results of regression show that collective model is significant. But if we see significance in separate variables we may come to know that pay and recognition show insignificance but promotion opportunity and meaningful work showing significance. Pay and recognition are insignificant at .312 and .801 respectively, whether pay and recognition has positive relationship with job satisfaction. These values show that there is no cause and effect relationship between pay and recognition with job satisfaction of doctors. But promotion opportunity and meaningful work are significant which shows that, there is cause and effect relationship between promotion opportunities and meaningful work with job satisfaction. In case of doctors they are dissatisfied due to their service structure, because government has no proper service structure of doctors. Pay and recognition is showing insignificancy it may be because pay and recognition is not a big issue. Government is providing reasonable pay to doctors and providing them recognition but not giving them promotion opportunity as well as meaningful work. This is the main reason of doctor's dissatisfaction.

\section{Limitation of the Study:}

There were some limitations which I have to bear while doing my research. Firstly, time was too short to do my research in a large scale. My research was in the overall region of Punjab, where I focus on main cities like Lahore, Faisalabad, Rawalpindi, Multan, and Bahawalpur. 
I could not include all cities of Punjab. Secondly, financial constraints came to across. Definitely we have not enough finance to do this research because for this research a large amount of money should be invested. Thirdly, this survey was based on self reporting, just like it may be based on subjective perception. Lastly, it might be possible that participants did not give us accurate data although we assured them for confidentiality of data.

\section{Future Direction:}

This study suggests the policy makers to make policies by which doctors can be satisfy. This study also reveals different issues that should be tackled by government to satisfy doctors. This study provides a base for future studies in different hospitals worldwide.

\section{Recommendations and Suggestions:}

1. The most important thing is that government should revise and make amendment in the service structure of doctors. Because the main reason of doctors dissatisfaction in Punjab is actually the service structure.

2. Salary structure of doctors should be revised annually and there should be proper structure of compensation that offer general increases, bonuses/incentives, fringe benefits equally at all levels.

3. Salaries should be according to the duties performed by the doctors and compensated according to their services, so that our human capital not has to go abroad (brain drain).

4. There should be proper grading system. As according to other sectors like manufacturing, judiciary and banking sector.

5. There is no proper system of security setting for doctors. Policy maker should made plan of physical security for doctors because according to Maslow theory security need is very important for every human being.

6. Doctors are unaware of a variety of benefits and incentives that they are receiving or they are allowed to receive for example health and insurance etc. Doctors should be aware of all these benefits. So let the doctors totally alert of all the benefits that they are permitted to receive.

7. Policy maker should made plan to improve the different services like to provide equipment and facilities to doctors so they can be motivated.

8. Government should focus on training programs (on the job and off the job) for doctors, job rotation and support the doctors so that they can feel valuable themselves.

9. House rent allowance should be fairly and equally distributed. And the policies which are effective and productive should be implemented effectively and efficiently.

10. There should be flexibility in terms of holidays so that doctors are not gone into the situation of much stress that lowers their services' quality.

11. Government should provide an equal chance of promotion in a fair and honest way.

12. Doctor's work should be meaningful enough to future success.

13. Government should implement proper performance management system to tackle the issues related to feedback, performance and promotions of doctors. 
14. Overall there should be an effective plan to compensate the doctors to meet the inflation of this dynamic environment so that doctors not to be frustrated.

\section{Conclusion:}

This research was conducted to know about different issues in compensation for doctors in civil hospitals. Findings show that the doctors should compensate properly in order to retain and motivate them. Brain-drain can only be removed if government properly compensates them.

Satisfaction with job is important element for motivation and performance of doctors. The main issue of doctor's dissatisfaction is the service structure. Because our findings also showing that pay and recognition may have direct relationship with job satisfaction but main issue is promotion opportunities and meaningful work which are not getting by doctors. To retain, motivate, government should focus on service structure, so that doctors come back to their work from strikes and work as they should do. There is also differences exist in mean value of different age group, experiences and income with job satisfaction but not in gender group. Doctors with high income and high experience are more satisfied than low income and low experience. It is assumed that

"Now-a-days, be a doctor is a curse..."

Doctors are on still their demands and will continue their strikes if their demands will not met by government.

\section{References:}

- A.-H. M. (2008). A Study of nurses' job satisfaction: The relationship to organizational commitment, perceived organizational support, transactional leadership, transformational leadership, and level of education. Eur. J. Sci. Res. , 22(2), 286-295.

- Al-Hussami, M. (2008). A study of nurses' job satisfaction: The relationship to organizational commitment, perceived organizational support, transactional leadership, transformational leadership and level of education, European Journal of Scientific Research, Vol. 22, No2: 286-285.

- Barton, G. M. (2002). Recognition at work. Scottsdale: World at Work.

- Bowie, N. E. (1998). A Kantian Theory of meaningful work. Journal of Business Ethics , 1083-1092.

- Caudron, S. (1997). The search for meaning at work. Training and Development, 51(9), 24-27.

- Danish, Q. D., \& Usman, A. (2010). Impact of reward and recognition on job satisfaction and motivation: An empirical study from Pakistan. International Journal of Business \& Management, 5(2), 159-167.

- De Souza, R. (2002). Walking upright here: Countering prevailing discourses through reflexivity and methodological pluralism. (Unpublished MA (Nursing) Thesis). Massey University, Albany, NZ.

- De Beer, M.J. (1987). 'n Ondersoek na die rol wat arbeidsomset in die bedryf speel met spesifieke verwysing na werkbevrediging en werksmotivering. Unpublished master's dissertation, University of the Free State, Bloemfontein. 


\section{Macrothink}

- Erasmus, B., Van Wyk, M., \& Schenk, H. (2001). South African Human Resource Management (2nd ed.). Cape Town: Juta \& Company Ltd.

- FRANKLIN, N. J. (2006, november 30). JOB SATISFACTION AS EXPERIENCED BY DOCTORS IN PUBLIC.

- Gary Dessler (2008), Human Resource Management, Prenctice Hall, America.

- Graham, H.T. (1986). Human resources management (5th ed.). London: Pitman Publishing.

- Grobler, P.A., Warnich, S., Carrell, M.R., Elbert, N.F., \& Hatfield, R.D. (2002). Human resource management in South Africa (2nd ed.). London: Thomson Learning.

- Hackman, J.R. \& Oldham, G.R. 1976. Motivation through the design of work: Test of a theory. Organizational Behavior and Human Performance, 16: 250-279.

- Herry, E., \& Noon, M. (2001). A dictionary of human resource management. New York: Oxford University Press.

- Kreitner, R. and Kinicki, A.2001. Organisational Behaviour. 5th ed. New York: McGraw Hill.

- Kabene, S. M. Orchard, C., Howard, J.M., Soriano, M. A., Leduc, R. (27 july 2006). The importance of human resources management in health care: a global context.

- Lawler, E. E. (2003). Treat people right. San Francisco: Jossey-Bass Inc. McGraw-Hill Irwin.

- Martineau, T., Lehman, U., Matwa, P., Kathyola, J. \& Storey, K. (2006) Factors affecting retention of different groups of rural health workers in Malawi and Eastern Cape Province, South Africa.

- Martocchio, J.J. (1998). Strategic Compensation. New Jersey: Prentice-Hall Inc.

- Mason, L.J. (2001). Retaining Key Personnel. Plus: Top 10 Retention Tips. Stress Education Center. Retrieved February 27, 2005, from http:www.dstress.com.

- Naveed, A. Usman, A. Bushra,F.(2011). Promotion: A Predictor of Job Satisfaction A Study of Glass Industry of Lahore (Pakistan). International Journal of Business and Social Science, Vol. 2 No. 16.

- Nel, P.S., Gerber, P.D., van Dyk, P.S., Haasbroek, G.D., Schultz, H.B., Sono, T., \& Werner, A. (2001). Human Resources Management. Cape Town: Oxford University Press.

- NL, D. M. (2012). Human Resources Responsibility on Job Satisfaction. Journal of Business and Management, 2278-487X Volume 2, Issue 1, PP 11-14.

- Parvin, M. M. \& Kabir, M.M (2011). FACTORS AFFECTING EMPLOYEE JOB SATISFACTION OF PHARMACEUTICAL SECTOR. Australian Journal of Business and Management Research, Vol.1 No.9 [113-123].

- Pocock, B (2006) The labour market ate my babies: work, children and a sustainable future. Sydney : Federation Press.

- Pratt, M.G., \& Ashforth, B.E. 2003. Fostering meaningfulness in working and work. In K.S. Cameron, J.E. Dutton \& R.E. Quinn (Eds.), Positive organizational scholarship: Foundations of a new discipline. San Francisco: Berrett-Koehler.

- RAMASODI, J. M. (2010). FACTORS INFLUENCING JOB SATISFACTION AMONG HEALTHCARE PROFESSIONALS AT SOUTH RAND HOSPITAL. 
- Ramayah, T., Jantan, M., Tadisina, K.S. (2001, November). JOB SATISFACTION: EMPIRICAL EVIDENCE FOR ALTERNATIVES TO JDI.

- Robbins, S. P. (2001). Organisational Behaviour (9th ed.). New York: Prentice-Hall, Inc.

- Parvin, M. M. \& Kabir, M.M (2011). FACTORS AFFECTING EMPLOYEE JOB SATISFACTION OF PHARMACEUTICAL SECTOR. Australian Journal of Business and Management Research, Vol.1 No.9 [113-123].

- Robbins, S.P. 2003. Organisational Behaviour: Concepts, Controversies and Applications. 10th ed. New Jersey: Prentice Hall

- Romano, L. (2003). Beyond reward: why cash is no longer enough. Rewards, 3(1), 12-13.

- Sarvadi, P. (2005). The best way to reward employees. Solutions for growing Business. Retrieved February 27, 2005, from http:www.entrepreneur.com.

- Schleger, P.R. (1985). Approaches to training and development (2nd ed.). Canada: Addison-Wesley Publishing Company, Inc.

- Scroggins, W. A. (2008). Antecedents and Outcomes of Experienced Meaningful Work: A person job fit perspective . Journal of Business Inquiry , 68-78.

- Sharma, R. D., \& Jyoti, J. (2006). Job satisfaction among school teachers. IIMB Management Review, 18( 4), 349-363.

- Swann, W. B., Jr. (1990). To be adored or to be known? The interplay of self-enhancement and self-verification. In R. M. Sorrentino \& E. T. Higgins (Eds.), Motivation and cognition (vol. 2, pp. 408-448). New York: Guilford.

- Towers Perrin. (2003, April). Working today: The Towers Perrin 2003 talent report. New York: Author.

- Werner, A. Motivation in Human Resource Management. Cape Town: Oxford University Press, 2001:587.

- Yang, H., Miao, D., Zhu, X., Sun, Y., Liu, X. \& Wu, S. 2008. 'The influence of a pay increase on job satisfaction: A study with the Chinese army', Social Behaviour and Personality, 36(10): 1333-1340. 